\title{
CHARACTER EDUCATION IN AN ACEHNESE CULTURAL SAGA: HIKAYAT PRANG SABI
}

\author{
RN Herman'; Mukhlis²; Firman Parlindungan ${ }^{3 *}$; Lia Lisyati ${ }^{4}$ Rahmad Nuthihar ${ }^{5}$ \\ ${ }^{1,2}$ Department of Bahasa Indonesia Education, Universitas Syiah Kuala \\ Jl. Teuku Nyak Arief No. 441, Kopelma Darussalam, Kota Banda Aceh, Aceh 23111, Indonesia \\ ${ }^{3,4}$ Center for Curriculum and Language Development, Universitas Teuku Umar \\ Jl. Alue Peunyareng, Ujong Tanoh Darat, Meureubo, Aceh 23681, Indonesia \\ ${ }^{5}$ Department of Electrical Construction and Maintenance, Akademi Komunitas Negeri Aceh Barat, Meulaboh, Indonesia \\ Komplek STTU, Jl. Alue Peunyareng, Ujong Tanoh Darat, Meureubo, Aceh 23681, Indonesia \\ 'herman_rn@unsyiah.ac.id; ${ }^{2}$ mukhlishamid@gmail.com; ${ }^{3}$ firman@utu.ac.id; \\ ${ }^{4}$ lialisyati@gmail.com; ${ }^{5}$ rahmad.nuthihar@aknacehbarat.ac.id
}

Received: $13^{\text {th }}$ August 2020/Revised: $24^{\text {th }}$ August 2020/Accepted: $22^{\text {nd }}$ September 2020

\begin{abstract}
How to Cite: Herman, RN., Mukhlis., Parlindungan, F., Lisyati, L., \& Nuthihar, R. (2020). Character education in an Acehnese cultural saga: Hikayat Prang Sabi. Lingua Cultura, 14(2), 179-186.

https://doi.org/10.21512/lc.v14i2.6623
\end{abstract}

\begin{abstract}
The research sought to understand the value of patriotism in the Hikayat Prang Sabi by using a qualitative approach. Hikayat was referred to narratives (saga) of war rooted in Acehnese cultural tradition, and Prang Sabi in Acehnese language meant 'Holy War'. As a literary work, Hikayat Prang Sabi embodied the concept of jihad, which was usually sung during the time of war in the Acehnese history: Portuguese in 1511, Dutch in 1873, Japan in 1942, and the Republic of Indonesia in 1976. The source of the data was verses or stanzas of Hikayat Prang Sabi that contained patriotic values. These verses were then treated as the unit of analysis. A hermeneutic approach was employed to analyze the data. The findings show that Hikayat Prang Sabi contains two types of patriotic values: national and religious. National value refers to the sense of nationalism, ethnicity, and humanity. Religious value, on the other hand, displays the value of spirituality, prophecy, and peace. These values indicate the foundation of thinking and doing of the Acehnese people manifested in a literary work, which then can be transferred into the notion of character education.
\end{abstract}

Keywords: character education, Acehnese culture, war saga

\section{INTRODUCTION}

Aceh has a long history of wars and armed conflicts. In 1511, Aceh was in a war against Portuguese colonialism which wanted to control trade in Aceh. In 1873, the Dutch helped the Acehnese to take control over the Portuguese but ended up declaring war against the Acehnese (Muhammad, Sukiman, \& Irwansyah, 2019). This war was more heroic than the war against the Portuguese in which the people of Aceh were still able to maintain the ethnic groups and regions of Aceh. When the Netherlands had not completely departed from Aceh, Japan invaded in 1942. However, the people of Aceh remained resistant. There was no word of surrender. Those people volunteered to die on the battlefield. Therefore, the Dutch war journalist,
Zentgraaff noted that, "Even if a bomb is planted in every strand of grass that grows on the land of Aceh, Aceh would never be destroyed" (as cited in Yuliati et al., 2020).

The long war of Aceh continued to the armed conflict period where Aceh was in the social revolution in late 1945 to early 1946 (known as Cumbok war). Later in 1953, Daud Beureueh, an Acehnese figure, established a rebellion called Darul Islam against the Republic of Indonesia to found the Islamic State in Aceh. However, he capitulated in 1962. In 1976, a new rebellion movement called Gerakan Aceh Merdeka (GAM, Free Aceh Movement) was founded by Muhammad Hasan Tiro, fighting for Islamic ideology and socioeconomic equality against the Republic of Indonesia. Since then, Aceh was in armed conflict with 
the Indonesian military until the Helsinki Agreement in 2005. Both parties agreed to live in peace, and Aceh is part of the Republic of Indonesia (Dhuhri, 2016).

The persistence of the Acehnese people to survive in the burdens of war is inseparable from the values embedded in every Acehnese person (Mursyidin et al., 2020). Many studies have stated that that Acehnese people hold values that are in line with Islamic teaching originated from the sacred texts; the Quran dan the Hadith (Abubakar, Srimulyani, \& Anwar, 2019; Rizki, 2019). Additionally, the cultural values of the Acehnese people are also reflected in their literary works, such as hikayat (saga), which contains the narrative of patriotism and bravery of the people during the time of war (Aristora, 2017; Baihaqi, Imran, \& Yakob, 2017). Those studies have shed light on the importance of hikayat in the life of Acehnese people, particularly Hikayat Prang Sabi, which is mainly discussed from the perspective of jihad. In the research, jihad is defined in Islamic concepts as warfare from the Arabic word, which means 'to endeavor', 'to strive' (Parrot, 2020). Hikayat Prang Sabi is defined as 'Holy War', a war in the path of jihad.

Instilling the value of patriotism to the youth is necessarily important. In this regard, the government plays a major role in fostering the acquisition process, which can be implemented in an educational context. In Aceh, where the majority of its people are Muslim, the teaching of patriotism and Islamic values are commonly intertwined in school. According to Strunkina et al. (2016), religious-based education is likely to be a solution dealing with problems triggered by developing concepts of national and patriotic upbringing. Besides, because Aceh is an area that has a history of conflict between the Government of the Republic of Indonesia and the Aceh Separative Movement (GAM), reframing the teaching of patriotic values in school is very urgent in order to reinforce social harmony and conflict resolution to the youth (Anwar, 2019). This practice is also important to minimize any possible conflict in the future within society (Sanusi et al., 2018).

As a case in point, Saritoprak, Exline, and Stauner (2018) have studied how Hikayat Prang Sabi becomes the center of gravity of jihad in Aceh history. They point out that since jihad is equal to obligatory worship in Islamic teaching, its universal values are infused within Hikayat Prang Sabi, which is introduced in the Acehnese cultural practice since a young age. Hikayat Prang Sabi is more than ordinary poetry because it generally contains religious values extracted from the Qur'an and the Hadith to spur Acehnese spirit in defending their religion, nation, and state.

However, little is known about the values of Hikayat Prang Sabi from the perspective of patriotism, which might be relevant to the notion of character education. The research is interested in discovering what patriotic values are embedded in the Hikayat Prang Sabi, which might be transferred into character education, especially the one related to Islamic scholarship. Nuthihar and Luthfi (2019) have pointed out that Hikayat Prang Sabi is heavily influenced by Islamic Sufism (philosophy), which is closely related to the sociocultural practice where the society resides. Additionally, Widyahening and Wardhani (2016) have also mentioned that literary works might contain values that might be applicable to character education. This statement is in line with Hasjmy's (1977) groundbreaking research on Hikayat Prang Sabi, which mentioned that as a literary text, Hikayat Prang Sabi has the power to encourage the people of Aceh in three social domains; education, religion, and literature.

This literary text is considered a narrative (saga) of a holy war, which contains inspirational and heroic values. Acehnese has long been inspired by this saga to increase their collective spirit of patriotism. Historically, it was sung by Acehnese poets during the time of war. For example, during the Dutch war, whoever listens to Hikayat Prang Sabi, his enthusiasm immediately surged, his soul of jihad appeared immediately. Therefore, the Netherlands strongly prohibited the circulation of this saga in the Acehnese community at that time. Any Acehnese who was found singing or saving the text of this saga would be captured. Therefore, after 1924, it was difficult to find the text of the Hikayat Prang Sabi. This saga is then more often heard verbally by word of mouth (Zahrul, 2016).

In line with the discussion, there is a growing notion of character education which is mainly oriented as a framework to strengthen human personality in the form of attitude, mentality, and mindset (Allen \& Bull, 2018; Baehr, 2017; Jeynes, 2017). This notion reinforces the position of Hikayat Prang Sabi as a pivotal literary work that might be used as the foundation for character education. This text contains various values in the form of character and moral education, which is conveyed through stories of the past and Islamic perspectives.

From the Islamic perspective, the foundation of character education refers to the four characteristics of the Prophet Muhammad Peace Be Upon Him; (1) Siddiq, which means trustworthy, (2) Amanah, which means honesty, (3) Tabliq, which means conveying, and (4) Fatanah which means intelligent (Herman et al., 2018). These four characteristics of the prophet appear in the text of Hikayat Prang Sabi, complementing patriotic values. It can be said that being trustworthy, honest, conveying, and intelligent are values that every human should have. This is what makes Hikayat Prang Sabi as a relevant text within the character education framework. Judging from its usefulness, Hodairiyah, Rais, and Purnanto (2019) have argued that the use of literary text in character education is relevant since it provides a mediation to describe a meaning for societies and to maintain local values for the next generation.

It can be concluded that Hikayat Prang Sabi has enriched current knowledge on literature and character education. This saga plays an essential role 
for the people of Aceh. However, limited studies have found that focus on the value of patriotism as a concept of character education in the Hikayat Prang Sabi. Thus, the research fills the gap by discussing the patriotic values of Hikayat Prang Sabi and its association with character education. Pedagogically speaking, the research provides theoretical grounds for teachers to incorporate cultural values in designing learning materials, including cultural sensitivity and appropriation, which are relevant to the student's cultural backgrounds (Parlindungan, Rifai, \& Safriani, 2018).

\section{METHODS}

The research provides a descriptive and systematic description of the values of patriotism embedded in Hikayat Prang Sabi. A qualitative approach (Creswell, 2016) is employed to explore what patriotic values that are embedded in Hikayat Prang Sabi. The source of the data is each verse or stanza that contains patriotic values. The collected verses treated as units of analysis are then analyzed by using hermeneutic approach to literature.

Gius and Jacke (2017) have mentioned that the hermeneutic approach is suitable to be used in analyzing literary texts because this approach: (1) relates to the interpretation of the scriptures, (2) is as a method of philology, (3) is as a science of linguistic understanding, (4) is as a geisteswissenschafi methodology or the universal interpretation of human life, (5) is as a phenomenology of understanding, and (6) is as a system of interpretation. On this basis, hermeneutics is considered as having a significant role in interpreting texts (Hughes, Shaw, \& Greenhalgh, 2020).

\section{RESULTS AND DISCUSSIONS}

Patriotic values in Hikayat Prang Sabi have become a fundamental factor in developing the sense of Acehnese patriotism as well as national patriotism. The author of Hikayat Prang Sabi points out that patriotic characters embedded in the concept of jihad have become the foundation of the Acehnese Muslim jihad. In general, patriotic values contained in Hikayat Prang Sabi can be divided into two aspects; religious patriotism and national patriotism.

The first value constituted with patriotism in Hikayat Prang Sabi is a religious value. Religious value is understood as a patriot attitude that relies on the commands of Allah, God. This concept of religious patriotism cannot be separated from the Quran and the Hadith. Kollner (2016) has emphasized that patriotism and religion have a strong relationship that makes them fit into each other. On the one hand, religion is used to build a nation and institution, as well as to strengthen patriotism. On the other hand, patriotic value is used in religious education to strengthen the culture and identity of the society.

Religious value relates to possessing a will to sacrifice for the sake of religion, for the sake of carrying out the commands of Allah, the Almighty. This is why Hikayat Prang Sabi always mentions that those who are willing to die on the path of God are Shaheed, the martyrs. God promises that the reward for those who die within this situation is heaven, the highest sacred position where believers are rewarded hereafter. God's promise to this in Hikayat Prang Sabi can be seen in the following stanza. Table 1 is the examples of data on religious patriotism value.

Table 1 Religious Patriotism

\begin{tabular}{|c|c|}
\hline Aceh & English \\
\hline $\begin{array}{l}\text { He teungku tjut adoe } \\
\text { sahbat }\end{array}$ & O my dear my brothers \\
\hline $\begin{array}{l}\text { Peureuman Hadarat } \\
\text { Tuhanku Rabbi }\end{array}$ & $\begin{array}{l}\text { Obey your God the } \\
\text { almighty }\end{array}$ \\
\hline $\begin{array}{l}\text { Sigala njang na dum } \\
\text { ibadat }\end{array}$ & $\begin{array}{l}\text { All worships bound to } \\
\text { you }\end{array}$ \\
\hline $\begin{array}{l}\text { Njang leubeh that } \\
\text { djakprang sabi }\end{array}$ & $\begin{array}{l}\text { Most of which is a holy } \\
\text { war }\end{array}$ \\
\hline $\begin{array}{l}\text { Hadih Nabi tjit that } \\
\text { saheh }\end{array}$ & $\begin{array}{l}\text { Hadith of the Prophet is } \\
\text { indeed truthful }\end{array}$ \\
\hline $\begin{array}{l}\text { Hana ret weh bak prang } \\
\text { sabi }\end{array}$ & $\begin{array}{l}\text { Do not abandon the holy } \\
\text { war }\end{array}$ \\
\hline $\begin{array}{l}\text { Neubri bulueng han } \\
\text { peudaleh }\end{array}$ & $\begin{array}{l}\text { Give an effort not an } \\
\text { excuse }\end{array}$ \\
\hline $\begin{array}{l}\text { Tjit ka teupreh suruga } \\
\text { tinggi }\end{array}$ & $\begin{array}{l}\text { The best paradise awaits } \\
\text { you }\end{array}$ \\
\hline $\begin{array}{l}\text { Soe njang na djok } \\
\text { nyawong hareuta }\end{array}$ & $\begin{array}{l}\text { Whoever contributes his } \\
\text { soul and wealth }\end{array}$ \\
\hline $\begin{array}{l}\text { Geu peulandja bak } \\
\text { prang sabi }\end{array}$ & $\begin{array}{l}\text { Spend everything for the } \\
\text { holy war }\end{array}$ \\
\hline $\begin{array}{l}\text { Neu bloe le Po meuhai } \\
\text { hareuga }\end{array}$ & $\begin{array}{l}\text { Although it indeed is } \\
\text { expensive }\end{array}$ \\
\hline $\begin{array}{l}\text { Deungon suruga neu } \\
\text { tuka geubri }\end{array}$ & $\begin{array}{l}\text { The paradise awaits in } \\
\text { return }\end{array}$ \\
\hline
\end{tabular}

Table 1 shows the stanzas about the religious concept that fosters an attitude of patriotism for everyone who hears or reads Hikayat Prang Sabi. The first stanza says that going to holy war is God's command. This is reinforced in the next stanza, which mentions that there is a valid hadith about Prang Sabi or holy war. The stanzas attempt to emphasize that those who are willing to sacrifice their wealth and live in Prang Sabi will be guaranteed the highest paradise level as their reward. Motivated by this promise, people's attitudes and spirit of jihad are expected to lift. This is in line with what is expressed by Saritoprak, Exline, and Stauner (2018) that spiritual jihad cannot be performed alone. It must be supported by the sacrifice of wealth. 
In this sense, jihad is conceived as a much broader concept in Islam, which includes difficult acts of charity and spiritual struggle against satan and the lower self (Parrot, 2020). This sacrifice is considered as part of patriot characteristics, an attitude that is not concerned with wealth. It is because, in the Islamic principle, loving wealth means ignoring Allah's commands. Based on the story passed down from generation to generation, it is believed that the concept of jihad had boosted up the patriotism of Acehnese when they heard Hikayat Prang Sabi. This statement has been depicted many times in the text. For example, in the last stanza (Table 2), it describes that a strong will to sacrifice for the sake of religion will make a person never die. Even if he dies, he will die with high dignity and forever live within the spirit of the still alive people.

Table 2 The Value of Religious Patriotism

\begin{tabular}{|c|c|}
\hline Aceh & $\begin{array}{c}\text { English } \\
\end{array}$ \\
\hline $\begin{array}{l}\text { Gopnyanudép bak poteu } \\
\text { Allah }\end{array}$ & $\begin{array}{l}\text { They live by the side of } \\
\text { Allah }\end{array}$ \\
\hline $\begin{array}{l}\text { Dalam kubah } \\
\text { syurugamanyang }\end{array}$ & $\begin{array}{l}\text { In the dome of the } \\
\text { heaven }\end{array}$ \\
\hline $\begin{array}{l}\text { Boh lam rumba } \\
\text { meuhpuwo laju }\end{array}$ & Just take home the body \\
\hline Beuthattaeukaseulintang & $\begin{array}{l}\text { Although it seems in } \\
\text { misery }\end{array}$ \\
\hline Beuthatthan le taue rupa & $\begin{array}{l}\text { Although we do not see } \\
\text { each other anymore }\end{array}$ \\
\hline $\begin{array}{l}\text { Bek tasangkagopnyan } \\
\text { mate }\end{array}$ & $\begin{array}{l}\text { Do not think they are } \\
\text { death }\end{array}$ \\
\hline $\begin{array}{l}\text { Peureuman Tuhan } \\
\text { tjitdeuh rupa }\end{array}$ & $\begin{array}{l}\text { The work of Allah is } \\
\text { visible }\end{array}$ \\
\hline $\begin{array}{l}\text { Bek jok sangka he } \\
\text { bohhate }\end{array}$ & $\begin{array}{l}\text { Do not make assumption } \\
\text { o my dear }\end{array}$ \\
\hline Maté syahid hana sakét & $\begin{array}{l}\text { Dead by martyr is in no } \\
\text { pain }\end{array}$ \\
\hline $\begin{array}{l}\text { Duemgeucutiet- } \\
\text { gukèekeuranjang }\end{array}$ & $\begin{array}{l}\text { It is like being pricked } \\
\text { by a thorn }\end{array}$ \\
\hline $\begin{array}{l}\text { Ureueng syahid } \\
\text { bèktakheunmaté }\end{array}$ & A martyr is not dead \\
\hline $\begin{array}{l}\text { Beutatthanléie rupa } \\
\text { tapandang }\end{array}$ & $\begin{array}{l}\text { Although we no longer } \\
\text { see each other }\end{array}$ \\
\hline
\end{tabular}

Table 2 shows that the stanzas try to foster the spirit of jihad for all Acehnese Muslims, so they will not be afraid to die on the holy battlefield. The poet of this saga wants to convey that people who die, shaheed, are role models for everyone. Spiritually, they never die, although their bodies no longer exist in the real world. With this message, the author shapes the patriotism character of the Acehnese people so that they are never afraid of facing the holy battlefield. Today, this patriotic attitude might be transformed into character education for all Acehnese and every Muslim in general (Jamil, 2019). This view is strengthened by Gusacov (2018) saying that character education that focuses on patriotic values may improve shared meaning within the society in constructing social solidarity. People may learn the history of their society in the past and improve their sense of social solidarity today through character education.

Hikayat Prang Sabi describes the attitude of the Acehnese people in dealing with death that is never fearing death. This value presents the philosophical character of the Acehnese people. Table 3 shows the data from Hikayat Prang Sabi that encourages Acehnese not to fear death.

Table 3 Hikayat Prang Sabi on Religious Value

\begin{tabular}{|c|c|}
\hline Aceh & English \\
\hline He syedara bek taduek le & $\begin{array}{l}\text { O brothers do not just sit } \\
\text { there }\end{array}$ \\
\hline $\begin{array}{l}\text { Jak prang kaphe wahe } \\
\text { abang }\end{array}$ & $\begin{array}{l}\text { Let us fight the infidels, } \\
\text { o brothers }\end{array}$ \\
\hline Ikot suroh Rabboljale & Obey your God \\
\hline Han sabe pahla muprang & $\begin{array}{l}\text { The reward of war is not } \\
\text { the same }\end{array}$ \\
\hline $\begin{array}{l}\text { Sigala dum na nyang } \\
\text { taibadat }\end{array}$ & $\begin{array}{l}\text { All of forms of worship } \\
\text { that we do }\end{array}$ \\
\hline $\begin{array}{l}\text { Nyang leubeh that jak } \\
\text { muprang }\end{array}$ & $\begin{array}{l}\text { The best one is going to } \\
\text { holy war }\end{array}$ \\
\hline $\begin{array}{l}\text { Bek tasangka wahe } \\
\text { sahbat }\end{array}$ & Do not assume o brothers \\
\hline $\begin{array}{l}\text { Bak prang meuhat mate } \\
\text { rijang }\end{array}$ & $\begin{array}{l}\text { That in the holy war } \\
\text { death is near }\end{array}$ \\
\hline
\end{tabular}

The two stanzas in Table 3 are written in the form of questions and answers. The first stanza is a question of the invitation to fight, not afraid of death for the sake of carrying out God's commands. The second stanza is the answer from the previous stanza, which states that no matter how much the reward is obtained from various worship services in general, the rewards of holy war are still greater than all the existing rewards. Again, the spirit of jihad is also salient in these stanzas. God's favor of jihad motivates many Muslims in the world to choose to fight. Jihad in Islam has some conditions, such as not leaving the main obligation (e.g., wife, parents). However, it should be noted that Hikayat Prang Sabi was written in the past when Aceh was in the context of war. Its use to spur the spirit of jihad for a holy war might not be relevant today, but its spirit to build social harmony is still urgent. As a case in point, Indonesia today is not in the state of war, so Hikayat Prang Sabi today may not be used for the purpose of war. Instead, it is applicable to improve social harmony through character education, which is in line with the spirit of Pancasila. Thus, the Hikayat Prang Sabi not only attempts to raise a patriotic 
attitude of fighting in a holy war but also maintains to prioritize social matters.

The second patriotic value entailed in Hikayat Prang Sabi is related to nationalism. National value in Hikayat Prang Sabi also lies in the Islamic perspective. There is a hadith mentioning that love of the motherland is a part of having faith. In this sense, nationalism has used an approach to enter modernity through the lens of religion and become the community of faith (Biard, 2017). This community of faith then participates in the integration of nation-state and religion. Love of the motherland means possessing a will to sacrifice for the motherland. A will to die defending the motherland is certainly an attitude of patriotism that should be developed by everyone. The author of Hikayat Prang Sabi conveys the message that loving homeland means being willing to die as a shaheed (martyr) for the homeland, ethnicity, and race, as pictured in Table 3. Hikayat Prang Sabi manifests patriotic values of nationalism because it is necessary to encourage people to love their motherland in the context of war. In today's context, embedding such values to the youth generation is undoubtedly important to prevent sentiments and conflicts within society. Schlosser (2017) has mentioned that conflict may take place when national unity is destroyed and patriotism is undermined. To strengthen the idea, Westheimer (2019) has suggested that teachers, researchers, and policymakers should expand the list of words used to describe patriotism manifested in different forms of attitudes, beliefs, and actions, including national patriotism. To this end, national patriotism is conceived as not only about serving for the motherland but also about pride in the nation, state, ethnicity, and race (Omelchenko et al., 2015). Table 4 shows the reference of the data on national patriotism in Hikayat Prang Sabi.

Table 4 The Value of National Patriotism

\begin{tabular}{|c|c|}
\hline Aceh & English \\
\hline Po geutanyoe kuasa that & $\begin{array}{l}\text { Our lord is indeed the } \\
\text { greatest }\end{array}$ \\
\hline $\begin{array}{l}\text { Geuyubeurangkat lawan } \\
\text { Belanda }\end{array}$ & $\begin{array}{l}\text { Ordered us to fight } \\
\text { against the Dutch }\end{array}$ \\
\hline Yohgohgeuyu le hadarat & $\begin{array}{l}\text { Before being asked by } \\
\text { the people }\end{array}$ \\
\hline Djinoetakarat he syedara & $\begin{array}{l}\text { Go immediately o my } \\
\text { brother }\end{array}$ \\
\hline $\begin{array}{l}\text { He ureueng mukmin } \\
\text { tapohmusoh }\end{array}$ & $\begin{array}{l}\text { O believer let us slay the } \\
\text { enemy }\end{array}$ \\
\hline $\begin{array}{l}\text { Muprangbeusung- } \\
\text { gohngonBeulanda }\end{array}$ & $\begin{array}{l}\text { Fight firmly with the } \\
\text { Dutch }\end{array}$ \\
\hline $\begin{array}{l}\text { Hate bak } \\
\text { teutapwaherakan }\end{array}$ & $\begin{array}{l}\text { Strengthen your heart o } \\
\text { my brother }\end{array}$ \\
\hline $\begin{array}{l}\text { Tulong Tuhan troh bak } \\
\text { gata }\end{array}$ & $\begin{array}{l}\text { The help of your God is } \\
\text { with you }\end{array}$ \\
\hline
\end{tabular}

Table 4 The Value of National Patriotism (Continued)

\begin{tabular}{ll}
\hline \multicolumn{1}{c}{ Aceh } & \multicolumn{1}{c}{ English } \\
\hline $\begin{array}{l}\text { Geubriseksanjangthat- } \\
\text { peudeh }\end{array}$ & $\begin{array}{l}\text { The torment is indeed } \\
\text { painful }\end{array}$ \\
$\begin{array}{l}\text { Soe njang han } \\
\text { patehprangBeulanda }\end{array}$ & $\begin{array}{l}\text { For whoever do not fight } \\
\text { against the Dutch }\end{array}$ \\
$\begin{array}{l}\text { Wateemeuseukirad- } \\
\text { jakureh }\end{array}$ & $\begin{array}{l}\text { If you go fight against } \\
\text { the Dutch }\end{array}$ \\
$\begin{array}{l}\text { BeuthatwarehSaidil } \\
\text { Anbiya }\end{array}$ & $\begin{array}{l}\text { You will be together with } \\
\text { the leader of the Prophet }\end{array}$ \\
\hline
\end{tabular}

Table 4 shows that the author of Hikayat Prang Sabi illustrates a character of Acehnese patriotism. It is exemplified by the invitation to fight the Dutch because, at that time, they colonized Aceh. The author of Hikayat Prang Sabi also intends to bring up the spirit of jihad of Acehnese people by participating in the war against The Dutch as an effort to defend their homeland (Aceh), ethnicity, and race. Regardless of the power that The Dutch had during colonialism, according to the author of the saga, the Acehnese people considered it as a call for patriotism as well as the fulfillment of God's command. They are, therefore, able to gain spiritual strength to join in the battlefield.

The patriot value displayed in the stanzas is a manifestation of Acehnese characters who are tough, persistent, and enthusiastic. For the people of Aceh, defending the nation, homeland, and ethnicity is a philosophy of life. This is stated in a hadih maja (Acehnese proverb); "pantang peudeueng mubalek sarong, pantang reuncong mubalek mata; pantang ureueng diteu'oh kawom, pantang hukom dipeujeut peukara" (A sword sheath must not be put inside out, a rencong - Acehnese dagger - must not be held mistakenly, people must not live in the clan, the law must not be questioned). This proverb adds to the patriotism of the Acehnese that following the formal regulation of the state (law) is obligatory in which all people should defend it in all circumstances.

Acehnese people must not stand silenced when their nation and descendants are challenged and questioned. This is the value that ignited the fighting spirit of the Acehnese so that they were able to survive in each period of war, including the period of war against the Portuguese, the Dutch, and the Republic of Indonesia. Developing national patriotism is necessary to be implemented widely to sustain national unity as Arnot, Casely-Hayford, and Yeboah (2018) have recommended that the awareness of national unity and harmony can be promoted through respecting its constitutions, laws, and symbols.

The persistence of the Acehnese people in fighting and never giving up is an attitude of patriotism that has long been narrated in literature. Not only drafted in a written version, but the sense of patriotism of Acehnese people has also been reflected in their real-life interaction. The finding in the research is in line with Unsriana and Ningrum's research (2018). 
They have examined the moral principle in a Japanese elementary school textbook entitled "Watashitachi no Doutoku" and its correlation with the character formation of children in Japan. The textbook encourages the students to instill the value of a high level of discipline. Not only that this value is used in the educational setting, but it also is accepted by the Japanese society at large. The educational setting is indeed the best setting to formally build the character of the people (Permana \& Suhaili, 2019).

A similar argument is also found in Sofiani, Akhadiah, and Emzir's research (2019), who argue that character and identity are closely related to the social context of society. As part of society, students create a certain identity, which is a socio-emotional process that involves a change in their emotions, personality, and relationship with others where they live. That being said, character education considers the relationship between the individual citizen and the social community, which might include recognizing and challenging social injustices and deliberative engagement with the difference among the society (Peterson, 2019).

\section{CONCLUSIONS}

The research focuses on the patriotic values embedded in an Acehnese cultural saga called Hikayat Prang Sabi or literally translated into English as a holy war narrative. In particular, the research seeks to discover what patriotic values (i.e., national and religious) are embedded in the Hikayat Prang Sabi, which might be transferred into character education, especially the one related to Islamic principles. Character education is the manifestation of character derived from any other sources (e.g., literature, philosophy) to strengthen moral and civic virtues like generosity, tolerance, kindness, and others. The findings show that patriotic values in Hikayat Prang Sabi entail two distinct values; religion and nationalism. Religious values are related to attitudes based on religion, while nationalism values are related to attitudes to sacrifice for the motherland.

Patriotism is an attitude that shapes a person's character to be willing to sacrifice, both for the sake of religion and for the sake of the nation and state. That is, willingness to sacrifice is a character that is supposed to be possessed by people. In the Hikayat Prang Sabi, patriotism is a value that lives in Acehnese society. The value has become the foundation of thinking and doing, including determining attitudes in defense of religion, nation, and state (Cojocariu, 2013). The author of Hikayat Prang Sabi indicates that the patriotic attitude of the Acehnese is strongly influenced by the stories of the Prophet Muhammad. These inspirational stories are found in the Hikayat Prang Sabi as a concept of jihad as well as character education. These patriotic values written in the saga are manifested by the Acehnese in their daily social interaction.
This research has some limitations. First, it only focuses on the content of Hikayat Prang Sabi that entails character education. The units of analysis are verses or stanzas of the saga and their interpretations of a character's values. This research does not focus further on the linguistic aspects of the saga, such as how the language is structured, how meanings are constructed, and how people use and perceive the language. Second, this research specifically focuses on the patriotic values of Hikayat Prang Sabi. Since the saga embedded the Acehnese cultures and norms at large, it may contain other values and philosophical ways of thinking and doing, which may not necessarily be related to just patriotic values.

Thus, further research is needed to investigate Hikayat Prang Sabi in more varied scopes and contexts. For example, further studies might focus on the linguistic aspects of the saga or how it is being used in the school context in association with the implementation of character education. Further studies that employ a different method of inquiry are also needed. Future researchers might be interested in studying the effectiveness of Hikayat Prang Sabi in improving students' characters using experimental studies. Its relation to other outcome constructs, such as literacy, creativity, critical thinking, and language mastery, is also worth studying.

\section{REFERENCES}

Abubakar, A., Srimulyani, E., \& Anwar, A. (2019). Identification of some distinctive values of Acehnese Malee (Shyness) for character education. Jurnal Ilmiah Peuradeun: The International Journal of Social Science, 7(1), 125-140. http://dx.doi. org/10.26811/peuradeun.v7i1.224.

Allen, K., \& Bull, A. (2018). Following policy: A network ethnography of the UK character education policy community. SociologicalResearch Online, 23(2), 438458. https://doi.org/10.1177/1360780418769678.

Anwar, E. (2019). Becoming better muslims: Religious authority and ethical improvement in Aceh, Indonesia by David Kloos. Pacific Affairs, 92(2), 391-393.

Aristora, I. (2017). Dutch defeat about holy war saga in Aceh. In PASAK II. Malaysia. pp. 1-17.

Arnot, M., Casely-Hayford, L., \& Yeboah, T. (2018). Postcolonial dilemmas in the construction of Ghanaian citizenship education: National unity, human rights and social inequalities. International Journal of Educational Development, 61, 117-126. https://doi. org/10.1016/j.ijedudev.2017.12.008.

Baehr, J. (2017). The varieties of character and some implications for character education. Journal of Youth and Adolescence, 46(6), 1153-1161. https:// doi.org/10.1007/s10964-017-0654-z.

Baihaqi, B., Imran, I., Yakob, M. (2017). Understanding Acehnese literature in framing of nusantara literature. Proceeding of International Conference on Science, Technology, and Modern Society (ICSTMS). Aceh, Samudra University. 
Biard, A. (2017). Islam, ethno-nationalism, and transnational "faith community" in Kyrgyzstan. In Michel P., Possamai A., Turner B. (Eds), Religions, Nations, and Transnationalism in Multiple Modernities. New York: Palgrave Macmillan. https://doi. org/10.1057/978-1-137-58011-5_6.

Cojocariu, V. M. (2013). Petre ţuţea or some axiological anchors for a necessary patriotic education. Procedia - Social and Behavioral Sciences, 76, 204-208. https://doi.org/10.1016/j.sbspro.2013.04.099.

Creswell, J. W. (2016). Research design pendekatan kualitatif, kuantitatif, dan mixed. Yogyakarta: Pustaka Pelajar.

Dhuhri, S. (2016). Art as a cultural instrument: The role of Acehnese art in resolving horizontal conflict. Jurnal Ilmiah Peuradeun, 4(1), 89-102.

Gius, E., \& Jacke, J. (2017). The hermeneutic profit of annotation: On preventing and fostering disagreement in literary analysis. International Journal of Humanities and Arts Computing, 11(2), 233-254. https://doi.org/10.3366/ijhac.2017.0194.

Gusacov, E. (2018). Education for patriotism and the ArabIsraeli sector. International Journal of Educational Development, 60, 138-148. https://doi.org/10.1016/j. ijedudev.2017.11.005.

Hasjmy, A. (1977). Apa sebab rakyat Aceh sanggup berperang puluhan tahun melawan agressi Belanda? Jakarta: Bulan Bintang.

Herman, R. N., Mukhlis., Saiful., \& Sanusi. (2018). The concepts of prayer and respect as character education of Acehnese children. In Proceedings of the International Conference on the Roles of Parents in Shaping Children's Characters (ICECED). Banda Aceh, Indonesia. pp. 450-457.

Hodairiyah, H., Rais, W. A., \& Purnanto, D. (2019). The cultural meaning in verbal and non verbal expression represented in nyaébuh tradition of people in Aeng Tong-tong, Saronggi, Sumenep. Lingua Cultura, 13(4), 283-287. https://doi.org/10.21512/ lc.v13i4.5933.

Hughes, G., Shaw, S., \& Greenhalgh, T. (2020). Rethinking integrated care: A systematic hermeneutic review of the literature on integrated care strategies and concepts. The Milbank Quarterly, 98(2), 446-492. https://doi.org/10.1111/1468-0009.12459.

Jamil, T. M. (2019). Overcoming the social problems faced by contemporary Acehnese through the social political role of Acehnese clerics (Muslim scholars). Journal of Islamic Marketing, 11(1), 213-233. http:// dx.doi.org/10.1108/JIMA-03-2018-0047.

Jeynes, W.H. (2017). A meta-analysis on the relationship between character education and student achievement and behavioral outcomes. Education and Urban Society, 51(1), 33-71. https://doi. org/10.1177\%2F0013124517747681.

Kollner, T. (2016). Patriotism, orthodox religion and education: Empirical findings from contemporary Russia. Religion, State, and Society, 44(4), 366-386. https://doi.org/10.1080/09637494.2016.1246852.

Muhammad, M., Sukiman, S., \& Irwansyah, I. (2019). Social status shift and collapse of uleebalang in Aceh of 1900-1946. Budapest International Research and Critics Institute (BIRCI-Journal): Humanities and Social Sciences, 2(2), 36-47. https://doi. org/10.33258/birci.v2i2.235.

Mursyidin., Nuthihar, R., Wahdaniah., \& Herman, R. (2020). Understanding Acehnese proverbs and their relation to the community work ethics. IJELR: International Journal of Education, Language and Religion, 02(1), 11-16. https://doi.org/10.35308/ijelr.v2i1.2191.

Nuthihar, R., \& Luthfi. (2019). Nilai sufistik dalam lantunan doa karya Ricky Syahrani sebagai bahan bacaan anak. TAZKIR: Jurnal Penelitian Ilmu-Ilmu Sosial Dan Keislaman, 5(1), 97-106. https://doi. org/10.24952/tazkir.v5i1.

Omelchenko, D., Maximova, S., Avdeeva, G., Goncharova, N., Noyanzina, O., \& Surtaeva, O. (2015). Patriotic education and civic culture of youth in Russia: Sociological perspective. Procedia - Social and Behavioral Sciences, 190, 364-371. https://doi. org/10.1016/j.sbspro.2015.05.012.

Parlindungan, F., Rifai, I., \& Safriani, A. (2018). The representation of Indonesian cultural diversity in middle school English textbooks. Indonesian Journal of Applied Linguistics, 8(2), 289-302. https://doi. org/10.17509/ijal.v8i2.13276.

Parrot, J. (2020). Jihad in Islam: Just-war theory in the Quran and Sunnah. Retrieved from https://yaqeeninstitute. org/justin-parrott/jihad-in-islam-just-war-theory-inthe-quran-and-sunnah.

Permana, R., \& Suhaili, A. (2019). A study of character education transformation in the history of al-khairiyah through expertise course (MKK). Humanities and Social Sciences Reviews, 7(5), 564-570. https://doi. org/10.18510/hssr.2019.7566.

Peterson, A. (2019). Character education, the individual and the political. Journal of Moral Education, 49(2), 143-157. https://doi.org/10.1080/03057240.2019.16 53270 .

Rizki, S. (2019). Hikayat Prang Sabi: Acehnese jawi as a medium of successful da'wa. Proceedings of International Conference on Da'wa and Communication, 1(1), 170-183. https://doi. org/10.15642/icondac.v1i1.287.

Sanusi., Azwardi., Yusuf, R., \& Iqbal, M. (2018). The attitude of the language of ex-combatans and the victims of armed conflict of Aceh Post-MoU Helsinki. Jurnal Ilmiah Peuradeun, 6(3), 493-506. http://dx.doi.org/10.26811/peuradeun.v6i3.258.

Saritoprak, S. N., Exline, J. J., \& Stauner, N. (2018). Spiritual jihad among U.S. Muslims: Preliminary measurement and associations with well-being and growth. Religions, 9(5), 158-180. https://doi. org/10.3390/rel9050158.

Schlosser, K. (2017). Education and intimate war of position: The national security league's committee on patriotism through education. Political Geography, 60, 66-75. https://doi.org/10.1016/j. polgeo.2017.04.008.

Sofiani, N., Akhadiah, S., \& Emzir. (2019). The influence of social contexts towards the identity development of the main character in The Bluest Eye by Toni 
Morrison. Lingua Cultura, 13(4), 257-263. https:// doi.org/10.21512/lc.v13i4.6138.

Strunkina, T., Shmeleva, E., Okeansky, V., Okeansky, Z., \& Romanova, A. (2016). Sociocultural needs of young people as a resource for the formation of national identity. SHS Web of Conferences, 28, 01093. https:// doi.org/10.1051/shsconf/20162801093.

Unsriana, L., \& Ningrum, R. (2018). The character formation of children in Japan: A study of Japanese children textbook on moral education (doutoku). Lingua Cultura, 12(4), 363-367. https://doi.org/10.21512/ lc.v12i4.4270.

Westheimer, J. (2019). Civic education and the rise of populist nationalism. Peabody Journal of Education, 94(1), 4-16. https://doi. org/10.1080/0161956X.2019.1553581.
Widyahening, E. T., \& Wardhani, N. E. (2016). Literary works and character education. International Journal of Language and Litearature, 4(1), 176-180. https:// doi.org/10.15640/ijll.v4n1a20.

Yuliati., Khakim, M. N., Furzaen, A. R., \& Suwarno, E. I. (2020). Aceh women's contribution of military affairs during western colonialism in Indonesia. Proceedings of the International Conference On Social Studies, Globalisation And Technology (ICSSGT 2019). https://doi.org/10.2991/assehr.k.200803.028.

Zahrul, F. (2016). Politik Islam di Aceh dalam Hikayat Prang Sabi karya Tengku Chik Pante Kulu: Kajian estetika resepsi Hans Robert Jausz Zahrul Fadhi. Yogyakarta: Universitas Gadjah Mada. 